\title{
4
}

\section{Social Policy in India: One Hundred Years of the (Stifled) Social Question}

\author{
Sony Pellissery
}

\section{Introduction}

What social policy is possible in a context in which the culture denies equality between citizens but at the same time the constitution guarantees it? To answer this central question, I describe the way the "stifling" mechanism acts on the idea of the "social" from the point of view of interests, institutions, and international influences. I use "stifling" to indicate "non-recognition", an idea Hegel originally developed

\footnotetext{
This chapter is the result of a long engagement with the Centre for Interdisciplinary Research (ZiF), University of Bielefeld, Germany, since 2011. I would like to express my gratitude to Lutz Leisering, Ulrike Davy, and Benjamin Davy for the opportunity to engage with two subgroups of the $\mathrm{ZiF}$ research group from which this volume flows. Ideas presented in this chapter were mainly developed in consultation with different scholars in residence at $\mathrm{ZiF}$. I would also like to thank colleagues at the Institute of Public Policy, Bangalore, for inputs on the draft paper. Some of the articles in which these ideas were earlier published include Davy and Pellissery (2013), Pellissery et al. (2015), Pellissery (2016, 2017), and Pellissery and Anand (2017).
}

\section{S. Pellissery $(\bowtie)$}

Institute of Public Policy, National Law School of India University, Bengaluru, India

e-mail: sony.pellissery@stx.oxon.org

(C) The Author(s) 2021

L. Leisering (ed.), One Hundred Years of Social Protection, Global Dynamics of Social

Policy, https://doi.org/10.1007/978-3-030-54959-6_4 
(1807/1966) in his classic The Phenomenology of the Spirit ${ }^{1}$ to show how unequal relations develop. Usage of this framework is in tandem with the idea that "the core of citizenship is about recognition, not about material levelling" (Davy et al. 2013: 6).

"Social" in Indian languages refers to "belonging to a community". 2 This is very close to the early meaning of "social" in Greek and Roman traditions, in which we find human cohabitation described as the Aristotelian zoon politicon and in Latin as animal sociale (see contestations of this translation in Arendt 1958 and Kaufmann 2013). However, the "community" of reference in Indian languages is not a "public" from which we could derive a Marshallian "universal citizenship" (also see Tönnies 1887/2001; Arendt 1958). Rather, citizens derive their identity through their community affiliations - religious, regional, and castewhich thus produces differentiated citizenship (Young 2000). That is why Jayal (2011) contends that citizenship in the Indian context is delinked from welfare. However, the English-language usage of "social policy", "social welfare", "social issues", or "social service" in political discourses, academic contexts, budgets, and administrative settings gets close to the ideas of anti-poverty policies and, thus, the idea of the "social" ("social question with distributive aims") as Heclo (1995) or Kaufmann (2012, 2013) elucidates. The problematique of this chapter is how the "social question" in this context has only feebly addressed "social inequality", which is the key causative factor requiring social policy intervention.

This chapter is arranged in eight parts. Broadly, I aim to divide Indian history into different periods in which qualitative changes to the social

\footnotetext{
${ }^{1}$ Hegel refers to one individual's realisation of conscious existence and the impossibility of the counterpart's self-consciousness. This imbalance is created through the former fulfilling a "desire for recognition" and the negation of the same by the latter. Hegel wrote about this process in a highly condensed fashion (229-240). However, subsequent scholars (Fanon 1967; Mannoni 1962; Kojève 1969; Gadamer 1976; and Honneth 2014) have interpreted and elaborated on this rich text. See a good summary of these interpretations in Bulhan (1985) and Fraser and Honneth (2003). Communication forms the crux of the defining relationship between two human beings. It is exactly because of this that "intersubjective recognition constitutes a necessary prerequisite for attaining self-consciousness" (Honneth 2014: 4). This is a radical departure from Kant, who argued that self-consciousness is the Self observing its own consciousness. Several scholars today have applied the idea of recognition in social policy contexts. Charles Taylor (1992) argued that the politics of recognition is at the heart of justice.

${ }^{2}$ The expressions in Sanskrit-root languages (for instance, the Hindi language uses samajik) and Dravidian-root languages (for instance, the Tamil language uses samuha) refer to "community".
} 
question took place. In each of the historical settings, "stifling" of the social question took place in unique ways. In the first stage, the religious reforms addressed the social question in the context of culturally rooted inequality. In the second stage, the labour question in the context of the production process - particularly the Asiatic mode of production-is taken up. The third stage is the prioritising of political freedom over the "social question" in the context of anti-colonial movements. In the fourth period, the battle of ideas (on the social problem) between three prominent public intellectuals during the foundation of the republic is discussed. While these three public intellectuals had clear ideas on redistribution policies, their ideas on the identity question also shaped the valuation of social policies. The fifth and sixth periods referred to in the chapter analyse how two main identity categories in India (caste and religion) shaped the social question. The seventh part of the chapter discusses how prioritising economic development over the "social question" neglected addressing inequality. In the final section, I discuss how intellectual colonialism thrust the last nail in the coffin of the social question in India. This chapter demonstrates the ways in which the dominant social idea in each stage prevented the recognition of social inequality. These historical periods stifling the "social question" are inconsistent with the modernity that the nation-state wants to achieve and the functional aspirations of a heterogeneous population.

\section{Religious Reforms as Social Reforms}

To investigate the societal and cultural dimensions of the origins of the "social question" in India, one has to revisit the period 2000 years ago, because the rationalist challenge to authority systems (in this case religious systems) (comparable to the Enlightenment in Europe) began when the Buddha rejected God as well as the Hindu social order. Without a brief examination of this legacy, documenting the evolution of the "social question" in India would be incomplete. 
Hindu social order and ancient Indian jurisprudence 3 symbiotically evolved together. The caste system's organisation of society formed the primary pillar of India's political economy:4 "India has a unique social division: the (endogamous) caste system. Caste is class at a primitive level of production, a religious method of forming social consciousness in such a manner that the primary producer is deprived of his surplus with the minimum of coercion" (Kosambi 1954: 14; italics in original). Until 800 BCE, caste was not viewed as an institution of discrimination (or a "social problem" in the sense we understand today) since inter-dining and intermarriage was possible. During the late Bronze Age and early Iron Age, pastoral-nomadic communities developed into four castes. Kosambi (1955: 42) explains this development as follows:

The reason for caste stratification is the new productive basis, which had led to relations of production between groups, higher than in the tribal stage but with still primitive tools. Thus, we have a tenant of Brahminism for state policy that each caste and subcaste (jati), tribal district, guild, and even large family group had to be judged by its own particular laws, obviously because it was then a unit of production. Therefore, the state could not uniformise the juridical structure within groups, but only regulate transactions between groups. ${ }^{5}$

Religion was used to valorise some functions and devalue others. In other words, the actions of the highest caste (Brahmins), such as offering sacrifices, were most noble compared to the activities of the labouring caste (Shudras): "Brahminism had constructed the acts of tilling the land,

\footnotetext{
3 "India" as a nation-state is a recent construction as a result of colonisation and integration of several kingdoms. Prior to that, the expression used was "Hindustan", referring to the region near the Indus River. This had a geographic stretch roughly similar to that of South Asia today.

${ }^{4}$ Prominent academic works on caste have not taken the political economy approach seriously. The works of Max Weber and Louis Dumont (1966) emphasised the cultural dimensions of caste. In recent times, there is a renewed interest in examining the caste issue from this missing angle. Singh (2014) argues that underlying the issue of caste relations is property and land rights.

${ }^{5}$ Note that Kosambi uses the term "caste-class". B. R. Ambedkar and subsequent writers, for instance, Omvedt (2007), have emphasised that the caste system's origin is not "functional differentiation" as happened in the capitalist stage of European development. The caste system originated in the pre-capitalist mode of the production period. Ambedkar repeatedly maintained that caste is not "division of labour, but division of labourers".
} 
removing a carcass from the village, skinning a carcass, and transforming hide into leather as filthy. In other words, the whole process of human intercourse with nature, land, plants, and animals in productive and creative modes was constructed as unclean" (Iliah 2007: 303). The untouchables or dalits, who did menial jobs, were kept outside of formal Hindu society. ${ }^{6}$ This rigid caste structure, which prevented mobility, warranted a revolution.

Buddhism was that revolution in Aryan society circa 400 BCE. It began as a religious revolution and evolved into a social and political revolution (Ambedkar 1956/1987). It challenged the caste system, accepted members from the lower castes as priests (a role reserved for Brahmins, the highest caste, in Hinduism), and gave equal status to women. These were explicit challenges to the societal power structure. At the core of the Buddhist revolution was the principle of social equality. This was possible because of the reasoned rejection of God. King Ashoka (304-234 BCE) accepted these Buddhist ideas and put them into practice. As a result, the religious revolution became a social revolution and received the patronage of the state.

In response, Brahmanical forces solidified the caste system through much stricter laws that Manusmriti developed (Ambedkar 1956/1987), and the regime that succeeded King Ashoka persecuted Buddhists using the Manusmriti code of law (compiled between 200 BCE and 200 CE). The dharmic system codified during this period emphasised individuals' duties rather than rights, and it was considered the duty of every individual to work for the well-being of society (Sharma 1984). ${ }^{7}$

\footnotetext{
${ }^{6}$ Several scholars (for instance, Galanter 1984) have documented how discrimination was institutionalised through the legal system, which I need not repeat here.

${ }^{7}$ Various Hindu scriptures even defined not only individuals' duties but also their mutual relations; for example, "Stri dharma paddhati" defines married women's duties and "Rajadharma" defines a king's duties. Similarly, the "Ashram-dharma" prescribes an individual's duties during various life stages, and, according to this, it is an individual's duty to look after one's family, which includes the elders, ancestors, progeny, and other members of the family who need protection (Kane 1941). The joint-family system that emerged out of this idea has always provided a sense of protection and security for the elderly and disabled.
} 
The biggest assault on rationality is rejecting reason in favour of religious precepts: "Hindus observed untouchability and caste not because they were inhuman or wrong-headed. They observed caste because they were deeply religious" (Ambedkar 1936: 68). Thus, the very social philosophy of Hinduism focuses neither on the individual nor on society, but on "Brahminic supermen" (Haragopal and Sukumar 2007).

There have been similar challenges to the Hindu social order from time to time, such as the development of Jainism (500 BCE) or Sikhism (1500 CE), which were revolutionary religions and offered a dignified life outside of the Hindu caste system. During the medieval period, Bhakti saints (such as Kabir and Nanak) preached social equality and castelessness. In the nineteenth century, there was an intellectual renaissance during which many reformers (some influenced by Western thoughts) advocated for liberation and the abandonment of class and caste distinctions (see Thapar 1966). Ambedkar and millions of dalits converted to Buddhism in 1956. In a nutshell, what appears to be religious reform or conversion is a response to the systemic inability to raise the "social question" of inequality. In a later part of the chapter, we examine how social policies have responded to inequality, particularly that arising from caste discrimination. However, before that, we need to examine other institutional frames that contributed to the ideational architecture of social policies.

\section{"Asiatic" Stifling}

Marx first raised the question of why the history of the East was the history of religion. He did not discover the characteristics of feudalism in his analysis of India and China. In what he called the Asiatic mode of production (AMP), he identified two central reasons for this: "The stationary nature of this part of Asia, despite all the aimless activity on the political surface, can be completely explained by two mutually supporting circumstances: 1 . The public works system of the central government and, 2 .

\footnotetext{
${ }^{8}$ Ambedkar argues that the reason for the disappearance of Buddhism from India is Brahmanical persecution rather than Islamic invasion.
} 
Alongside this, the entire Empire which, apart from a few large cities, is an agglomeration of villages, each with its own distinct organisation and each forming its own small world" (Marx 1853). ${ }^{\text {? }}$

Some scholars have challenged this self-sufficiency theory of village life (Srinivas and Shah 1960). However, there is a consensus that the village was the centre of the agrarian production system, and private property ownership was absent before the advent of the British empire. In Grundrisse, Marx (1858) further expanded on this idea: "a part of their surplus labour belongs to the higher community". This would tremendously change during British rule:

The inordinate and unscrupulous greed of the East India Company caused gradual disintegration of these gram panchayats. The deliberate introduction of the Ryotwari system as against the village tenure system dealt a deathblow to the corporate life of the village republics. The centralisation of all executive and judicial powers in the hands of the British bureaucrats also deprived the village functionaries of their age-long powers and influence. (Agarwal 1946: 52)

This analysis has two implications for the term "social". First, as long as a surplus of labour served the British administration, the workers' question would remain dormant. Breman (1996) traces how the exploitation of dalit (outcast) labourers - the cultural conditions of whom I described in the previous section-intensified during British colonial rule. Marx (1853) himself commented that the Asiatic system created an unresisting human who was limited to a vegetative state; it "restrained the human mind within the smallest possible compass".

Second, the breaking of the common property system meant that many citizens did not own property and, thus, penury was rampant (Pellissery and Biswas 2012). The origins of this deprivation go back to

\footnotetext{
${ }^{9}$ Marx formed these views based on the works of François Bernier (1934) and documents from the British Empire. It is worth quoting one of the accounts of a governor of the Raj: "The village communities are little republics, having nearly everything they want within themselves, and almost independent of any foreign relations. They seem to last where nothing else lasts. Dynasty after dynasty tumbles down; revolution succeeds to revolution; Hindu, Pathan, Mughal, Maratha, Sikh, English, are masters in turn but the village communities remain the same" (Lord Metcalfe 1833: 470).
} 
the historical circumstances described in this section. At the same time, it is important to distinguish between the notion of "feudalism" as understood in Europe and India when the emergence of the social is discussed in these different contexts. In the Indian context, caste as an institution prevented functional differentiation (the defining feature of modernity in Europe), and labour was never valued. Labouring was the duty of the lower strata in the societal hierarchy to those who occupied higher positions. The imagined organic unity of the society without functional differentiation stifled the emergence of the idea of the social.

However, colonial rule had the potential to change this. In several countries, colonial rule provided a historical break from the past and a move from a traditional society to a modern society. But, what happened in India?

\section{Political Freedom over Social Justice}

One of the foundational experiences of the Indian population coming together as a nation-state is their struggle for freedom, which lasted for about a century (1857-1947). ${ }^{10}$ Did this struggle facilitate the rise of the "social question" so that all sections of society could come together against the colonial power? A section within the Congress party, which spearheaded the freedom struggle, argued that social reform (in a limited sense) must precede political reform. However, those who held the view that political reform and independence from the British was more important silenced the Social Reform Party. Ambedkar (1936: 28) analysed the reasons for this. He pointed out that the Social Reform Party was concerned with reforming the Hindu family and not wider concerns for the reorganisation of Hindu society:

The Social Conference was a body which mainly concerned itself with the reform of the high caste Hindu family. It consisted mostly of enlightened high-caste Hindus who did not feel the necessity for agitating for the

\footnotetext{
${ }^{10}$ The first organised revolt against the East India Company took place in 1857, after which the British crown directly took over the rule of India.
} 
abolition of caste or had not the courage to agitate for it. They felt quite naturally a great urge to remove such evils as enforced widowhood, child marriages, etc., evils which prevailed among them and which were personally felt by them. They did not stand up for the reform of the Hindu society. The battle that was fought centred round the question of the reform of the family. It did not relate to the social reform in the sense of the break-up of the caste system. It was never put in issue by the reformers. That is the reason why the Social Reform party lost.

Thus, the elitist nature of the freedom struggle and the fact that the writers of the constitution were English-speaking, Western-educated Indians were precedents to the suppression of important social questions.

The Drafting Committee Chairman of the Constituent Assembly, Ambedkar (1948) (who was from a low caste), strongly made this argument: "Democracy in India is only a top dressing, on an Indian soil, which is essentially undemocratic". He further cautioned that if inequality was not reduced, the poorest sections of Indian society would undo the constitution and democracy itself. The Constitution of 1950 specifically recognised two social groups as hugely disadvantaged. These groups were: Scheduled (listed in the constitution) Castes or dalits (literally meaning "broken" people: outcasts from the Hindu caste system and, therefore, untouchables. Note that the Constitution of India does not abolish the caste system but abolishes discrimination based on caste, creed, and language) and Scheduled Tribes or adivasis (people who lived in the forests or indigenous people). Presently, dalits constitute 16.6 per cent of the Indian population and adivasis constitute 8.5 per cent. ${ }^{11}$

These groups remained loyal supporters of the Congress party until the 1970 s when they realised that remaining within the Congress party system would not help them raise the question of inequality. Since the early 1980s, the Congress party system has withered, and the Bharatiya Janata Party (BJP) and regional parties have reaped the advantages of this. However, the leaders of the Congress party were not unanimous in their

\footnotetext{
${ }^{11}$ Various reports and studies (both by government agencies and civil society organisations) provide evidence of the discrimination against lower castes and adivasis in education, health, and access to public services, and an over-representation of these groups below the poverty line (for a synthesis of these reports, refer to World Bank 2011, which need not be repeated here).
} 
"ideas" of the social and the policy recourse they should take. In the next section, we will discuss these tensions.

\section{Three Ideas of the "Social" at the Founding Moment of India}

Three distinct development models and interventions existed in early independent India. We can trace their origins to the ideological leanings of three social reformers and policymakers of the nascent nation in the late 1940s. First, Mahatma Gandhi, icon of the Indian independence struggle, emphasised the disorder of the markets and, therefore, the need to pursue development based on local resources. His concept of swaraj (which literally means "self-rule") was an ideal combination of political and economic freedom by giving political power to the people and providing for individual emancipation, particularly for the poorest of the poor. Second, Jawaharlal Nehru, the first prime minister of the country, drew significant inspiration from Soviet planning models as well as capitalist advancements in Western Europe. He called for a development model that could combine both these approaches. His advocation for national development through public-sector industrialisation came in direct conflict with Gandhi's development model based on local resources. B. R. Ambedkar propounded a third development model: a social justice model for development. Coming from a historically excluded, lowercaste community, he emphasised "annihilation of the caste" for the success of social democracy.

All three of these influential leaders agreed on the urgency of the "social question". However, they differed significantly in their understanding of the "social" as well as the proper course of action that the state should take. Despite this, they agreed to put their differences aside (to build the nation-state), and all agreed to advance the "social". Chatterjee (2004: 36) captures this as the "antinomy between the homogenous national and the heterogeneous social". Let us look at the subtle differences between these three views, which is useful for understanding the underlying tension that required the stifling of the "social". 
Ambedkar's ideas focused primarily on the question of representation. He disagreed with Gandhi that development should be centred around the village (Ambedkar felt that the "village was a den of ignorance and exploitation" from which dalits should escape). ${ }^{12}$ In this dispute, he found an ally in Nehru who wanted to support industrialisation and urban progress. Fabian socialism ${ }^{13}$ deeply influenced Nehru. This led him to create several state-owned, state-operated, and state-controlled means of production. Some of these sectors included steel, transportation, telecommunications, mining, and electricity generation. The government used permits, high tax rates, and rationing to regulate private activity, property rights, and entrepreneurship. To a great extent, the pre-1980s' Indian developmental model was the Fabian Society version of socialism. Ambedkar was decidedly supportive of urbanisation and industrialisation because they would increase mobility for dalits (as an economist, he believed that industrialisation was the only economic alternative to lowproductivity agriculture). However, unlike Nehru, he stressed training and the reservation system (discussed in the next section in detail) for dalits to help them access new opportunities both in the workplace and in politics. He was against the Leftist strategy of striking. Compared to him, Nehru facilitated trade unions, on the one hand, and made truces with trade union leaders in order to avoid strikes, on the other. ${ }^{14}$

Gandhi, who explicitly withdrew from positions of power after independence, took strong exception to the Nehruvian industrialisation strategy, ${ }^{15}$ as well as the strategy of state control. According to Gandhi, the state machinery would work against the emancipation and full realisation of the individual.

Gandhian economic philosophy was strongly rooted in "trusteeship" because John Ruskin's book Unto This Last had inspired him during his

\footnotetext{
${ }^{12}$ Ambedkar's disagreement with Gandhi on the question of the political representation of marginalised classes also has important significance for this chapter. We will discuss this in the next section when we explore the effectiveness of the quota-based welfare system.

${ }^{13}$ The Fabian Society of Britain aimed to create a democratic socialism grounded on the principle of reforming the capitalism, rather than overthrowing the capitalism.

${ }^{14} \mathrm{I}$ am grateful to Professor Babu Mathew for introducing this insight into Nehruvian strategy.

${ }^{15}$ Sanyal (2007: 155) compares the Gandhi-Nehru debate on industrialisation to that of the debate between Lenin and Narodniks in Russia and discusses the paradox of the initial victory of Nehru and Narodniks and contemporary disenchantment with such capital-intensive models.
} 
studies in England. The idea of trusteeship also had origins in Indian scriptures and the belief that possessions are immoral and sinful. ${ }^{16}$ Thus, Gandhi believed that only moral conduct could lead one to the truth, and he contended that morality could not be translated using the language of rights and obligations. It is this conception of a duty-bound individual that informs Gandhi's views on human rights. On two occasions (first to H. G. Wells in 1940 and later to Dr Julian Huxley, DirectorGeneral of UNESCO, in 1947), Gandhi emphasised that the discourse on human rights is erroneous, and instead, duties should be emphasised and the rights would follow.

In his aspiration to give autonomy to each individual, he advocated for decentralised governance structures and self-rule. Such a decentralised governance structure would coordinate different autonomous village units. Ambedkar disagreed with this proposal and, instead, wanted a strong state that would contain the social forces that perpetuated casteism. It is also important to remember that Ambedkar, who once created the Labour Party (and who also went on to become a labour minister), was responsible for introducing several classical measures of labour protection, such as "minimum wage" (enacted in 1948), maternity benefits, and limited working hours, to India. The most significant of Ambedkar's contributions was the emancipation of oppressed castes through the reservation system.

\section{Did the Reservation System Achieve Its Goal?}

One of the key commitments of the Constitution of India was to improve the welfare of marginalised groups_-women, children, and oppressed castes. This commitment defined the social justice goals of the Constitution

\footnotetext{
${ }^{16}$ The monist philosophies of ancient Indian religions had several written texts (the Upanishads) during 700-100 BCE that articulated this. Most popular among them is Om. "That (Brahman) is infinite, and this (universe) is infinite. The infinite proceeds from the infinite. (Then) taking the infinitude of the infinite (universe), it remains as the infinite (Brahman) alone" (Brahadaranyaka Upanishad 5.1.1). This classical text on monism was composed in 700 BCE. A later text (written in $100 \mathrm{BCE}$ ) describes moral principles more directly: "Whatever there is change in this ephemeral world, all that must be enveloped by the Lord. By this renunciation, support yourself. Do not covet the wealth of anyone" (Verse 1 from the Isha Upanishad).
} 
of India and was operationalised through quota-based reservation policies. Over the years, this affirmative action strategy has defined the law of the land as well as shaped the political discussions on equality and social justice. However, what has been achieved?

The challenges to affirmative action in India were based on the criteria for inclusion in the reservation system. One argument was that economic criteria should be the only criteria for inclusion, and, therefore, only "backward groups" should receive the benefits of affirmative action. This position maintained that if any other criteria are used, the principle of "merit" would be sacrificed. However, others contested this view because caste-based discrimination is not merely economic. For example, despite being economically well off, one could experience social discrimination and, thus, barriers to both social and economic mobility. Ambedkar (1920) articulated this when he compared India to "a tower which had several storeys without a ladder or an entrance. One was to die in the storey in which one was born". Ambedkar argued that political representation with separate electorates was the ideal solution to this problem, but Gandhi opposed this. Gandhi argued that although he was from an upper caste, he could represent untouchables. They resolved this conflict through negotiations in the 1930s (known as the Poona Pact) and agreed to reserve seats for untouchables within the Hindu electorate. This model of representation has persisted till date.

Similar debates took place on the topic of untouchables' economic welfare. Nehru gave in to Ambedkar's arguments in practice but not in principle:

frankly...I would like to put an end to such reservations as still remain. But again, speaking frankly, I realise that in the present state of affairs in India that would be not a desirable thing to do, that is to say, in regard to the Scheduled Castes. I try not to look at it from the religious minority, but rather in the sense of helping backward groups in the country. ${ }^{17}$

He based his position on his conviction that caste was a division of labour (Ambedkar's argument that caste was a division of labourers). On this,

\footnotetext{
${ }^{17}$ Speech in the Constituent Assembly, 26 May 1949. Constituent Assembly on India Debates, Vol. VIII: 331.
} 
Nehru agreed with Gandhi, and, finally, the Constitution of India did not abolish the caste system, only caste-based untouchability.

Eventually, the argument for affirmative action based only on economic measures was rejected, and 15 per cent jobs, educational opportunities, and political positions were reserved for scheduled castes and 7.5 per cent for adivasis. This was in proportion to the population break down of these groups. The creation of a "schedule" and listing communities who were eligible to benefit from these quotas has been controversial. More and more groups wanted inclusion in these lists. From time to time, this schedule has been revised, primarily as a function of electoral politics. However, the argument for affirmative action based on economic criteria has persisted, and a commission was appointed in 1979 to identify "socially or educationally backward classes". This commission prepared a list of communities who fit the new economic and social criteria. This new list consisted of 52 per cent of India's population. After intense political opposition from upper castes, the government reserved 27 per cent of the novel reservations for the newly identified "Other Backward Classes". Eventually, the Supreme Court decreed that reserved positions cannot exceed 50 per cent (Indra Sawhney and others $v$. Union of India and others, 1992).

Originally, when the constitution was written, the authors planned for reservations for oppressed castes to last only 50 years. However, the deeprooted caste political system (mobilisation of castes on political lines to win elections) has made it nearly impossible to end any part of the affirmative action programme. Different types of groups' demands for reservations are increasing. In some states in India, quotas in particular employment categories have reached 75 per cent. Nationally, in 2019, an additional quota of 10 per cent was extended to economically weaker sections of the country in addition to the existing quotas outlined in the 124th Constitutional Amendment.

It is worth reflecting on how affirmative action has shaped ideas of the "social". There is no doubt that the material welfare of a large number of members of groups who benefit from affirmative action has increased. However, this has created a "creamy layer" within these oppressed groups and, eventually, divided members of these groups. This is clear based on the demand for sub-quotas" since some subgroups within these categories 
have never benefited from affirmative action, even while other subgroups have repeatedly benefited (Ramavat 2018). Critics of reservation have also pointed out its inability to address the intersectionality of disadvantage (e.g., women from marginalised groups). Furthermore, job opportunities in the public sector have declined in the wake of liberalisation because several governmental industries were outsourced to the private sector. $^{18}$

Even more interesting is the question of indigenous communities, which were recognised as "Scheduled Tribes". Internationally, India refused to recognise that India has an "indigenous" population since all Indians are historically from India (unlike in Canada, the USA, and Australia, where outsiders conquered and dispossessed local indigenous populations). ${ }^{19}$ Although the government domestically recognised the presence of indigenous people by listing them in the schedule, it had limited impact on the ground in terms of this group's quality of life. Thus, the Dhebar Commission was appointed in 1960 to address this challenge. This commission recommended that the schedule list $52 \mathrm{com}$ munities as "Particularly Vulnerable Tribal Groups" who require particular types and numbers of welfare interventions. ${ }^{20}$ The quota approach has been less successful, since larger market interventions deprive people of livelihoods, compared to the state welfare system. For instance, Das and Padel (2010) demonstrated how the nexus between the state and mining companies displaced indigenous communities from traditional land, where the indigenous communities had control over and access to natural resources. Furthermore, providing welfare does not make up for their loss

\footnotetext{
${ }^{18}$ In some sectors, there is a demand for quotas for private-sector jobs.

${ }^{19}$ India has refused to ratify the International Labour Organization (ILO) Convention No. 169 concerning indigenous and tribal peoples in independent countries, because the concept of "indigenous peoples" is not relevant to India and there is no need for external cooperation or evaluation, including from the United Nations (UN), for tribal development programmes in India (full report on this is available in the report of the Joint Stakeholders submission on the situation of the rights of indigenous people in India for the third cycle of the Universal Period Review [UPR] of India, 27th Session of the Human Rights Council [Apr-May 2017]. The report is accessible here: https:// www.upr-info.org/sites/default/files/document/india/session_27_-_may_2017/js46_upr27_ ind_e_main.pdf). It is also interesting to note that India has supported the United Nations Declaration on the Rights of Indigenous Peoples (UNDRIP), 2007, which is a non-binding agreement.

${ }^{20}$ As of 2020 , this number has increased to 75 .
} 
of land and resources, nor does it substantially improve their quality of life.

Most of the regional states in India and the union government have "social welfare departments" or "social justice departments". These departments have limited functions available to enforce the schemes designed for the two most disadvantaged communities — scheduled castes (dalits) and scheduled tribes (adivasis). This is indicative of the disconnect between the social and labour questions.

However, on a positive note, the reservation system recognised that the dominant communities had perpetuated historical injustices against these groups, which has tremendously energised localities where these scheduled groups were able to use legal recourse to end systems of injustice. This includes resisting violence, claiming rights to land, and demanding a proportionate share in welfare funds, cooperatives for economic enterprises, and other resources. These demands indicate these groups' increased representation in the polity. The effectiveness of political representation (compared to economic compensation through the quota system) is an indication that the "social question" is primarily political when it comes to questions of caste.

\section{Democracy's Coexistence with Religion}

As I explained in the first section of this chapter, the "social" was closely associated with the idea of community (including religion) in India. Thus, when the Republic of India adopted its modern constitution in 1950 - although there were differences of opinion about the nature of the "social" (as explained in the preceding section) - there was wide agreement that social justice was a key principle of the Indian constitution. However, it was only in 1972 (through the 42nd Amendment to the Constitution of India) ${ }^{21}$ that two key terms (socialist and secular) were added to the original terms: "sovereign", "democratic", and

\footnotetext{
${ }^{21}$ The $42 \mathrm{nd}$ Amendment to the Constitution was passed during a turbulent time in India's democracy, namely during the Congress government and the then prime minister Indira Gandhi's state of Emergency (25 June 1975-21 March 1977). One of the amendment's key aims was to make parliamentary powers dominant over those of the Supreme Court (Austin 1999).
} 
"republic" in the preamble 22 to the Indian constitution. How the single amendment added both "socialist" and "secular" shows the two terms' indivisible relationship in the Indian context. ${ }^{23}$ Therefore, both the delay in introducing these two ideas and their implications when added deserve our attention.

Secularism as a concept is important for understanding the rule of law in India: all citizens irrespective of their religious faith are treated equally. This idea developed during the struggle for independence, when Pakistan became a Muslim state and India positioned itself as a secular state. However, the contradictions of this position were clear. Leaders of the independence struggle, such as Bal Gangadhar Tilak and Gandhi, used Hindu texts and symbols to organise and bring people together against the British colonial rulers. Thus, the idea of secularism addresses the tense relationship between members of the majority religion (Hindus constituted about 85 per cent of the population) and members of minority religions. The Indian state does not have an official religion. Unlike the idea of secularism in Western constitutions (in which the separation of church and state is key), Indian secularism professes "pluralism" or the responsibility of the state to protect all religions and religious groups.

This advocacy of secularism has limited the social rights of citizens on matters of inheritance, maintenance, marriage, and divorce. Since the personal laws that govern individual conduct in these domains derive primarily from religious conventions and rules, very often there is a contradiction between state and personal laws. The contestation point of recent secular policies is whether to adopt a uniform civil code (spurning all personal religious-based laws) or not. This question primarily touches on gender (and family law) and, thus, has significance for social policy.

The Indian Constituent Assembly debated this question while framing the constitution and made uniform civil code an ideal to achieve in the

\footnotetext{
${ }^{22}$ Although courts decide certain matters, the preamble of the constitution has a radiating effect on their interpretations of certain topics (Mathew et al. 2020).

${ }^{23}$ The Congress government was overthrown via a democratic process after the Emergency. Although the subsequent government (the Janata Party) proposed two amendments (the 43rd and 44th) to restore the constitution, they did not completely succeed. At the same time, the Congress Party in opposition underwent an internal reassessment at this point in time. Some leaders within the Congress Party fought for the modernisation, socialisation, and democratisation of the party (Johari 1973).
} 
future. However, the question again publicly arose when a Muslim woman approached the court to grant her income maintenance from her husband, who had divorced her (after 43 years of married life and five children) per Muslim personal law. ${ }^{24}$ The woman pleaded her case under the Code of Criminal Procedure, which applied to all Indians. In 1985, the Supreme Court of India upheld the decisions of a lower court and maintained that, irrespective of the personal laws, the husband is obliged to provide income maintenance under the Code of Criminal Procedure. This judgement caused an uproar. While human rights groups celebrated the judgement as a victory for the protection of women, Muslim communities saw it as a state attack on their identity and rights.

Along similar lines, questions related to the inheritance of property arose in 1986 among Christians. Among Kerala Christians, the personal law provided a woman with only one-fourth of share in her father's property, whereas the son got the majority share. The Supreme Court of India decided that the Indian Succession Act provided for equal shares for both son and daughter. ${ }^{25}$ In another development in 2014, the Supreme Court decided that even though Muslim personal law prohibited the adoption of children, an Indian Muslim could legally adopt children. These cases have kept the discourse on whether to implement a uniform civil code alive. Paradoxically, in 2019, the Indian parliament dominated by the Hindu majoritarian party (Bharatiya Janata Party) made talaq (Islamic divorce) illegal, which progressive Muslim women had long demanded. While this move is viewed as a step towards a uniform civil code, it is also seen as an example of the majoritarian religion forcing its personal laws on minority religions. Several feminist groups have decried this as hypocrisy since the human rights of Hindu widows have not been addressed at all. In other words, the common denominator for a uniform civil code (if agreed to as a principle in a pluralist polity) should be women's welfare, not the standards of a majoritarian religion. Majoritarian standards (as in the case of a state religion) could be civil, but could also easily erode social rights.

\footnotetext{
${ }^{24}$ Mohd. Ahmed Khan v. Shah Bano Begum (1985 SCALE $767=1985$ SCR $844=1985$ SCC 556 = AIR 1985 SC 945).

${ }^{25}$ Mrs Mary Roy Etc. Etc v. State of Kerala \& Ors on 24 February 1986, AIR 1011, 1986 SCR (1) 371 .
} 


\section{Economic Development over the Social Question}

Independent India's development plans were not meant to reduce inequality. Poverty alleviation was only added in the fifth development plan (the late 1970s). The history of two concrete poverty interventions (that of land redistribution and industrialisation policy) will prove this point. First is the question of land reform. As I show in section "Religious Reforms as Social Reforms" of this chapter, colonial rule created property inequality. For a nation that is committed to the constitutional principle of equality, the redistribution of assets is an important step. Several assessments on land reforms (Appu 1996; Jeyaranjan et al. 2010; Pellissery et al. 2017) show some land transfer from a small section of upper-caste landlords to the middle and lower castes but not to the outcasts (dalits). The idea of land reform primarily came from the Communist Party, and communist ideology emphasises the class rather than the caste question. This explains why land reform strategy was the least effective when it came to the redistribution of land to dalits.

Second, industrialisation as a strategy involved state protections for capitalists, unlike in Europe, where capitalists emerged as entrepreneurs through industrial investment. A handful of industrialists in Bombay prepared the "Bombay Plan", which would become the blueprint for national development over the next few decades under Nehru (Chibber 2003). Although the Bombay Plan was not socialist (Pellissery et al. 2020), Nehru believed that industrialisation was possible without the suffering that Europe experienced, in contrast to Gandhi, who believed that industrialisation was inherently a problem.

After the initial balancing of investment in small-scale and large-scale industries, the Indian planning process hugely favoured capital-intensive large industries. The strategy was to extract surplus from agriculture to support the development of industry. As Chakraborty (1987: 21) states, "it was necessary for agriculture to contribute to the building up of a modern industrial sector by providing cheap labour and also cheap food". Thus, the capital-good hypothesis (the state should invest in the creation of tangible property such as machine tools) and the wage-good 
hypothesis (the state should invest in sectors where labour-intensive production will happen) simultaneously worked in India. Sanyal (2007: 167) argues that, although there was no surplus extraction, the very process of separating the means of labour from labour itself was sufficient to establish the process of primitive accumulation in early independent India.

India's development programmes were primarily "Five-Year Plans", inspired by the erstwhile socialist planning model of the Soviet Union. Sen (2017) considers the First Five-Year Plan (1951-56) not as a development plan but as a reconstruction of the economy that was completely damaged due to centuries of exploitation under British rule. The Second Plan (1956-61) began with an obligation to "increase the growth rate of the gross domestic product" by establishing publicly supported heavy industries. The emphasis of this plan was on rapid industrialisation and increasing the economy's savings rate. The Third and Fourth Plans were also designed to broadly focus on continuing the agenda set by the second plan.

Despite these different approaches, poverty still haunted the nation. Therefore, by the 1970s, the basic needs and poverty reduction approaches took centre stage. The Fifth Plan (1974-79) is considered an important milestone in the development trajectory of India because it is when the ideas of poverty alleviation entered the agenda of the planning process with the then prime minister Indira Gandhi coining the term "Garibi hatao" (eradicate poverty). Since then, all plans have attempted to balance economic development and welfare programmes. Later, the focus of development programmes shifted to industrial growth and boosting the national income.

To evaluate these development programmes from the "social question", we need to ask whether these plans recognised and addressed social inequality. At the outset, we can say that the reservation strategy addressed only "social inequality" since the constitution provided positive discrimination for "scheduled" populations (dalits and adivasis). However, this strategy actually created two classes of services in public institutions. Discrimination continued to prevail against socially ostracised groups. Two important arenas for social policy intervention-education and health care-have demonstrated the reality of the syndrome "services for the poor are poor services". Poor-quality services (for instance, teacher 
and doctor absenteeism from schools and hospitals) have alienated people from accessing these services.

The third intervention most aptly demonstrates how economic development has stifled the social question. The key concern for the sovereign state of India after independence was how to feed its citizens and build a hunger-free nation. In other words, the material dimension of the social question was recognised as early as the 1940s. Food importation policies of the 1950s gave way to what is known as the Green Revolution in the 1960s, which was based on biotechnological inventions. Three interlinked policies were introduced in the mid-1960s consisting of (1) output-price policies including minimum support prices for farmers when grains are procured, (2) input-price subsidies, and (3) a public distribution system (PDS) to provide relatively low-cost food grains without harming the interests of the producers. This new agricultural strategy was largely successful in increasing production, which more than doubled, from 63 million tons in 1965 to 154 million tons in 1991, and drastically reduced the need for food grain imports (Suryanarayana 1995). These asset-focused policies were completely blind to the question of rural labour, which the dalit communities primarily provided (Siegel 2018). In other words, despite achieving food sufficiency, the outcome was deprivation amidst plenty.

The arguments developed hitherto in this section should not be construed as ignorance of the artificial distinction between the "social and economic" (Mkandawire 2001; Midgley and Tang 2001). Development interventions have ingeniously brought these two together. However, whether developmental interventions have addressed social inequality directly is an open question. In the Indian context, the empirical examination of expenditure data shows how infrastructural projects gained more attention than social inequality.

We can observe two broad types of spending in the public finance accounts relevant to social policy. First is development expenditure, which includes spending on agriculture and allied activities, rural development, special area programmes, irrigation and flood control, energy, industry and minerals, transport and communications, science and technology, and environment. Second is money spent on social services, which includes expenditures on education, sports, art and culture, 
medical and public health, family welfare, water supply and sanitation, housing, welfare of historically deprived communities, labour and labour welfare, social security, nutrition, relief on account of natural calamities, and urban development.

As per the mandate of the Constitution of India, the majority of the social sectors fall under the domain of state governments, hence spending on their part is higher compared to the central government. Kaur et al. (2014) analysed the data available and concluded that state governments alone incur 80 per cent of government (both centre and state) expenditures on social services. The education and health services combined account for 60 per cent of the total social expenditures of state governments. Between 1990-91 and 2013-14, per capita social-sector spending recorded a threefold increase, of which education-sector spending increased by 2.7 and health-sector spending increased by 2.3 times. The majority of the increase in social-sector spending occurred after 2000 . However, despite this increase, India still remains below the international standard of expenditure in the social sector.

Apart from social expenditure data, the confirmation of our argument of the ineffectiveness of developmental expenditures to address social inequality is the demand for community-specific funds. General expenditures on both development and social welfare neglected the most disadvantaged sections of society-dalits and adivasis. This led to the demand for special component plans. These plans argued that state government budgets should allocate spending in proportion to the population for the welfare of these populations. For instance, 15 per cent of the union budget should be earmarked for dalits since 15 per cent of the population are dalits.

This is an example of how the "social question" may be populistically responded to within the aggregate democratic framework (Young 2000). Solidarity ideals of the "social" are dismissed in favour of appeasing fragmented vote banks. The "social" is no longer a tool to increase and encourage dialogue with other communities and to gain "recognition". Rather, recognition is reduced to gaining access to state resources for material well-being. 


\section{Authoritarian Democracy Stifles the "Social" Question}

The Hegelian tension of the citizen's two roles in the public sphere ${ }^{26}$ is absent in Indian discourses due to the post-colonial process of nationstate creation that several South Asian countries witnessed. Thus, the "social question" was transplanted to consolidate the legitimacy of the rulers of the post-colonial states, rather than challenge them (as happened in post-revolutionary France and, generally, in Europe by raising the social question). This approach demobilised the possibility of raising the social question. The demobilisation of the power of the people coexisted with an authoritarian democracy that could and did stifle the "social" question.

An important aspect of South Asian and, specifically, Indian democracy is the authoritarian nature of the democratic leaders (Baxter 1985; Jalal 1995), especially the leaders of political parties (and thus national leaders). These parties appoint leaders based on their ascriptive identities, such as family lineage, membership in the aristocracy, or even descent from erstwhile feudal rulers (or provincial kings). The patronage these leaders provide to the local population enables them to win elections through the democratic process and to retain their positions of power.

This authoritarian democracy has had a crucial impact on the limits and opportunities for raising the social question within the polity, three aspects of which deserve specific attention within this chapter. The first implication of authoritarian democracy is the lack of responsiveness to the welfare question. Since elections are won on different criteria (e.g., patronage or religious identity), the indirect accountability model ${ }^{27}$

\footnotetext{
${ }^{26}$ The two roles of a citizen are "as a citizen (citoyen) of the state and as a member (bourgeois) of civil society" (Kaufmann 2012: 63). Partha Chatterjee (2004: 38) dismisses the role of the citoyen-in which a citizen has rights. He does so because only a small elite who have access to the state apparatus could enforce these rights. The majority of citizens have to resort to politics to enforce their rights. Therefore, he proposes the concept of "political society" in a subaltern context.

${ }^{27}$ The indirect accountability model describes the ability of service recipients to demand services directly from service providers. Compared to this, the direct accountability model outlines the power of electors to hold the elected responsible through their ability to vote them out of power if they do not deliver services. Elected representatives indirectly influence bureaucrats to improve their services (World Bank 2004).
} 
(World Bank 2004) fails. A political model that fails to generate a social question produces a large vacuum in society. Vibrant civil society voices in the form of non-governmental organisations (NGO) and media sources then fill this vacuum. In the late 1960s, there was a surge of these organisations, because political non-responsiveness to the poverty question was evident throughout the Congress Party's uninterrupted rule of over 20 years (Chandhoke 1995). The term NGO became identified with development agencies. Most NGOs operated as an extended arm of the government in remote areas of the country where bureaucracy had limited reach. ${ }^{28}$ Their grassroots-level contacts made them more effective agencies for raising the social question in a contextualised manner.

A report in 2015 stated that India had 3.2 million registered NGOs: "Indians have more per capita NGOs than hospital beds" (Down to Earth 2005). The Central Statistical Organisation of India noted the existence of "four NGOs for every 1,000 people in urban areas and 2.3 NGOs for every 1,000 people in rural areas". This spectacular growth was largely due to funding from foreign countries, particularly from the Global North. Funding agencies found that the government was an inefficient agent of development and social service delivery, so they began to route resources directly through NGOs. However, the question that is relevant for this chapter is whether NGOs can raise the social question. An answer to that question becomes clear as we examine the second implication of authoritarian regimes for the social question in South Asia.

The second implication of authoritarian democracy is the capture of bureaucracy. ${ }^{29}$ The bureaucracy (including the judiciary) fails to perform its role as a countervailing force to the legislative branch. The subordinated bureaucracy must serve the objectives of the elected politicians rather than the people. Thus, the direct model of accountability also fails. Elected politicians primarily control the bureaucracy through appoint-

\footnotetext{
${ }^{28}$ As I mentioned earlier in this chapter, each village acted as an autonomous republic, treating those outside the moral community of the village as aliens (on the moral community of the village, please refer to Platteau [1990] for the debate on the distinction between the rational and moral peasant with reference to the implications for social security).

${ }^{29}$ The current Indian Administrative Service (IAS) is patterned after the former Indian Civil Service of British India (or ICSI). Apart from central government-appointed civil servants, who may serve in any part of the country, the regional state governments also appoint civil servants, who may serve in any part of the state.
} 
ments and transfers (Wade 1985). Furthermore, bureaucrats operate in constituencies, where politicians are elected on patronage grounds and require middlemen to fulfil their promises (Reddy and Haragopal 1985; Pellissery 2006). In other words, governance is, in fact, collusion between the politician and the bureaucrat. The key breeding ground for corruption is this collusion, which requires detailed elaboration later in this section. The second generation of NGOs resisted this arrangement. Especially after a brief spell of Emergency rule in the country (June 1975 to January 1977), several bureaucrats, disillusioned by the politicians, resigned and decided to work in the civil society space. The NGOs they worked for were not merely an extended arm of the government; instead, they encouraged citizens to challenge what the elected government was doing.

The third implication of authoritarian democracy for the social question is the paradoxical operation of "trust". Rothstein (2005) successfully demonstrates that trust is the cement of institutions to deal with the "social" problem. Authoritarian regimes roll out welfare programmes to perpetuate their patronage relationship with the electorate. ${ }^{30}$ Thus, the patronage modality in the context of social cleavage destroys "system trust". Citizens trust individual politicians but not the political system. This paradoxical trust breeds corruption. The bribe that a citizen pays to a politician is viewed as a "gift" for the politician or bureaucrat's extra efforts (Pellissery and Bopaiah 2020). This is the fertile ground for the capture of the modern institutions by the traditional power sources.

All the three illnesses emanating from authoritarian democracy point out that, unless nurtured and adapted to the cultural settings, even the institution of democracy could be counter-productive to the "social".

\footnotetext{
${ }^{30}$ As shown by Keefer and Khemani (2005) in the context of information asymmetry in developing countries, the public choice approach is optimal because it provides welfare only to the targeted population rather than to everyone. This could translate as politicians reaching out to their own voter blocs often organised as religious or social groups.
} 


\section{Ideational Stifling from International Regimes}

Various scholars (including the author of this chapter), and prominently Ambedkar, have shown that the "social question" is not indigenous to Indian philosophy and religion. However, has borrowing ideas from elsewhere facilitated the raising of the social question in a meaningful manner in India? The most telling aspect of this question is the political responses to the question of inequality. India has witnessed the political mobilisation of both left-wing and right-wing ideologies. Both these political ideologies succumbed to Western notions of class, while the question of inequality is not addressed. The Indian variant of class-caste interplay (Pellissery et al. 2015) was neglected. Leftist political parties, ${ }^{31}$ which rose to power in some of the states through the democratic process (including Kerala, West Bengal, and Tripura) by championing the causes of the working class and poor, also completely ignored how caste creates inequality (Rajan 2003). ${ }^{32}$ This disappointment with left-wing politics is why identity-based political parties emerged in the late 1970s. They were generally known as "samaj" (community or caste) or political parties that made the social question their core.

Failure to raise the contextualised social question is attributable to intellectual colonialism that persisted through the funded projects, evaluation schemes, and policy advocacies of international organisations, such as the World Bank, the WTO, and UNICEF. In the rest of this section, I examine, in detail, a case study ${ }^{33}$ of the ways in which ILO operations in India distorted one of the social questions.

India, as a colony of Britain, was a founding member of the ILO. Yet, ILO conventions had very little impact on raising the "social question" and increasing labour welfare for Indian workers until independence. Tensions between the ILO and India became apparent on ratification of some conventions after independence. What requires our attention is the

\footnotetext{
${ }^{31}$ It is also interesting to note that by the mid-1970s, leftist political parties were vertically split between "Communist Party Marxists" and "Communist Party of India", primarily on the degree to which they were dogmatic.

${ }^{32}$ Globally, this is similar to how leftist political groups have ignored the feminist question.

${ }^{33}$ The case study is primarily informed by the research work at Centre for Labour Studies at the Institute of Public Policy, Bangalore.
} 
International Conventions on Forced Labour (C029 of 1930) and the Abolition of Forced Labour (C105 of 1957), among other international human rights instruments. India has ratified these conventions. However, in the 1940s, the Indian Constituent Assembly's discussion on forced labour was without any reference to the ILO convention of 1930.

The caste-based system of forced labour was endemic to Indian society and did not require debt as a form of coercion for its perpetuation. There was widespread recognition of this coercive system at the beginning of the process of consulting on and drafting the Indian constitution. The Constituent Assembly extensively discussed "begar", a then-prevalent form of forced labour, and, as a result, drafted and passed Article 23 of the 1950 Constitution of India, granting people a fundamental right not to be exploited through traffic in human beings, begar, and other forms of forced labour (with the exception of state-enforced public service, as long as it was imposed in a uniform, non-discriminatory manner).

After 25 years, through another unique law-the 1976 Bonded Labour System (Abolition) Act-India prohibited a wide gamut of bonded labour practices. The bonded labour system was primarily based on the caste-based exploitation of lower scheduled castes and tribes by the upper castes. ${ }^{34}$ Other legislative measures like the 1989 Scheduled Castes and Tribes (Prevention of Atrocities) Act provided a broad framework of legislative measures to challenge caste oppression. ${ }^{35}$ These were in conjunction with measures for positive discrimination programmes (discussed extensively in an earlier section) in education and employment to address the systematic caste oppression in India.

There was a marked difference between the ILO's conceptualisation of "forced labour" and India's conceptualisation. Combined with their stance on slavery (including modern slavery), the ILO's definition imagined employers' (including the state as an employer) exploitation of

\footnotetext{
${ }^{34}$ Evenforty-three years after the enactment of the Bonded Labour System (Abolition) Act, forced and bonded labour continue to be prevalent in India. As of 2018, the Ministry of Labour reported having earmarked money for the rehabilitation of 289,222 workers rescued from bonded labour. In the absence of disaggregated government statistics on bonded labour, this remains the most reliable authoritative figure.

${ }^{35}$ In the year 2013 alone, all over India, 39,327 crimes committed against dalits were reported. Out of these, 13,975 cases were registered under this law.
} 
employees using "force". The Indian definition used the term "bonded labour system" to indicate that force emerged from the caste system rather than a transaction between two individuals.

These differing conceptualisations also gave rise to divergent strategies. The ILO emphasised the identification and rescue of individuals trapped in forced labour arrangements. In contrast, India emphasised the transformation of the polity by ending the bonded labour system. India also emphasised the rehabilitation of former bonded labourers by providing alternative livelihoods directly.

Furthermore, the ILO emphasised criminalising the use of forced labour. Criminalisation as a strategy to achieve social aims is antagonistic to the ideal of solidarity. This is specifically true when the perpetrators of forced labour, as they are in this context, are farmers on whom a labourer depends for a job in their community. Criminalisation creates a rupture in a community, affecting the possibility of employment for labourers. However, criminalisation is a continuation of the individualisation of social rights since 1993 and in tandem with the state's neoliberal strategy of retreating from positive action ${ }^{36}$ (Davy 2013). This is the beginning of the era of providing for "social rights" in the form of material well-being while underplaying the need to uphold citizens' civil and political rights.

\section{Conclusion}

The central question this chapter aimed to address is the potential and possibility of social policy in contexts in which equality among citizens is culturally denied but at the same time constitutionally guaranteed. Unlike Breman et al. (2019), this chapter argued for the need to broaden the scope of analysis beyond Marxist class analysis when we considered the social question. This chapter demonstrated how effected reforms and changes - religious, social, economic, developmental, and political (see Table 4.1 for a summary)_were denied the full recognition of the

\footnotetext{
${ }^{36}$ See Nussbaum's (2003) articulation of the difference between positive liberty in the Indian constitution and negative liberty in the American constitution.
} 


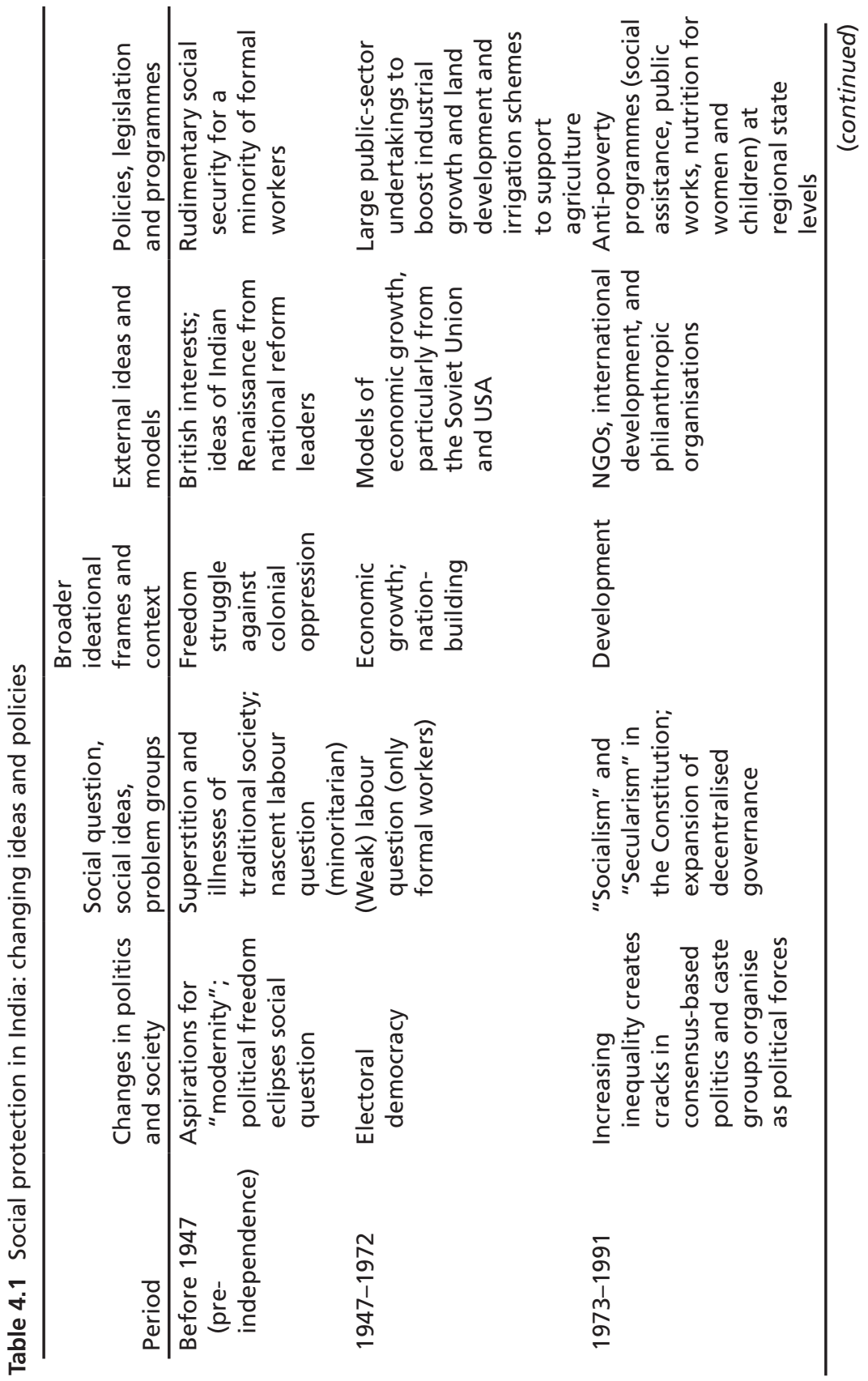




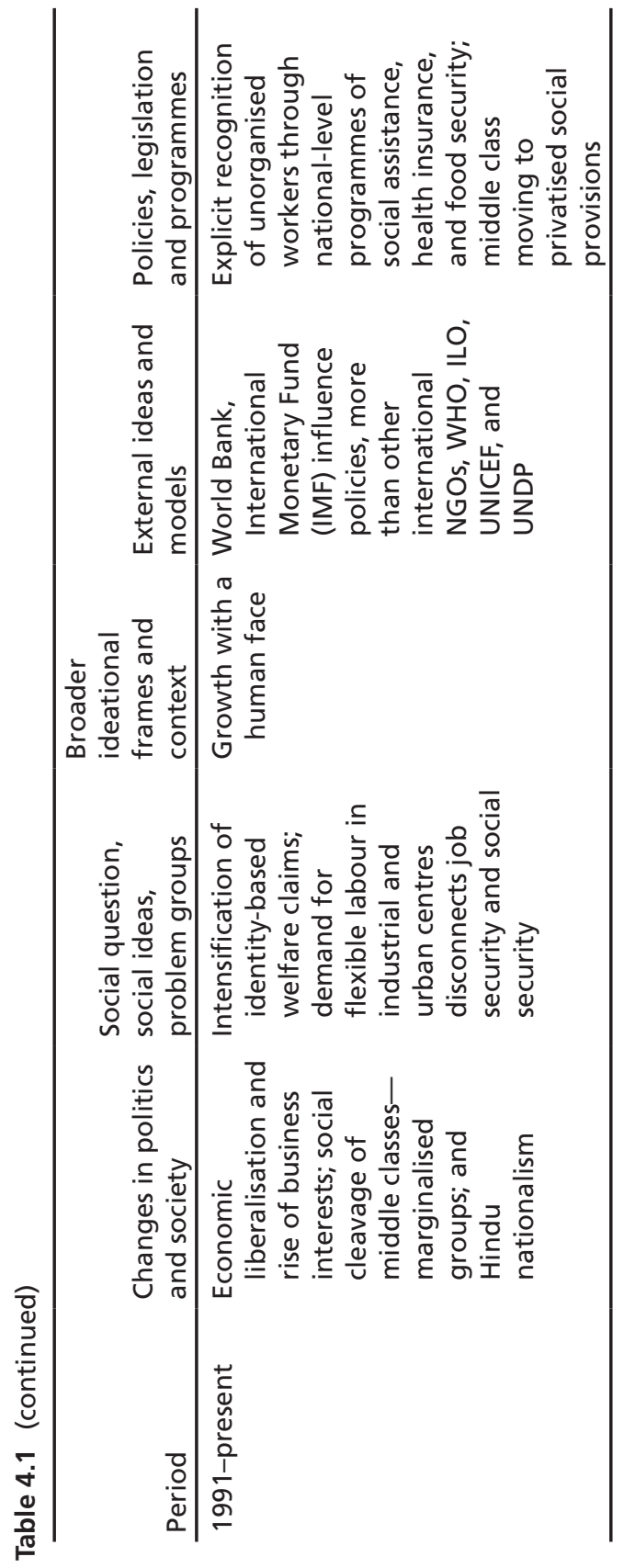


problem of inequality. In other words, the Indian polity has sidestepped the "social question" of group inequality during different historical phases.

This chapter has shown that prior to the formation of the modern Indian state, several attempts to raise the social question were thwarted as a result of a strong, socially held, religious philosophy and feudal control over the peasantry. The possibility of raising the social question was lost during the independence struggle since political priorities dominated. Similarly, after independence was won, against the background of nationstate construction, unity among the various leaders forced them to set aside their differences on "social" problems. By the time "social" issues were formally recognised as a state objective in the mid-1970s, the country had a divisive political scene. The middle class was solidifying, and the social question was beginning to be perceived as partisan. These series of historical efforts to stifle the "social question" are inconsistent with the modernity that the nation-state wants to achieve and the functional aspirations of a heterogeneous population.

If the "social" question in independent India had to be appropriately framed within a modernist frame, it should have been within a Hindu reformation frame, that is, a challenge to the internal contradictions of Hindu social philosophy in the light of the modernist values of the midtwentieth century. Policies focusing on redistribution and representation have fallen short. A rediscovery of public sphere, where recognition is the core of moral economy, is essential to achieve this ideal (Table 4.1).

\section{References}

Agarwal, Shriman Narayan (1946) Gandhian Constitution for free India. Retrieved from: cadindia.clpr.org.in (accessed on 01/01/2020). Ambedkar, Bimrao Ramji (1920) Editorial. Mooknayak (newspaper) first issue. Ambedkar, Bimrao Ramji (1936) Annibilation of caste. Ambedkar Institute of Social and Economic Change, Mumbai.

Ambedkar, Bimrao Ramji (1948) 'Draft constitution' a speech delivered in the Constitutional Assembly. The Constitution and the Constituent Assembly Debates, Lok Sabha Secretariat, Delhi, 1990, 107-13; 1171-183. 
Ambedkar, Bimrao Ramji (1956/1987) Cultural revolution and counter revolution. In Writings and Speeches, Dr. Babasaheb Ambedkar, Government of Maharashtra, Mumbai.

Appu, P. S. (1996) Land reforms in India. New Delhi: Vikas Publishers.

Austin, Granville (1999) Working a democratic constitution - the Indian experience. Delhi: Oxford University Press.

Arendt, Hannah (1958) Human condition. Chicago: University of Chicago Press. Baxter, Craig (1985) Democracy and authoritarianism in South Asia. Journal of International Affairs 38,2: 307-319.

Bernier, Francois (1934) Travels in the Mogul Empire: 1656-1668. Oxford: Oxford University Press.

Breman, Jan (1996) Footloose labour. Cambridge: Cambridge University Press.

Breman, Jan, Kevan, Harris, Ching Kwan Lee, and Marcel van der Linden (2019) The social question in the 21st century. California: University of California Press.

Bulhan, Hussein Abdilahi (1985) Frantz Fanon and the psychology of oppression. New York: Springer Science.

Chandhoke, Neera (1995) State and civil society: explorations in political theory. Delhi: Sage Publications.

Chakraborty, Sukhamoy (1987) Development planning: the Indian experience. Delhi: Oxford University Press.

Chatterjee, Partha (2004) The politics of the governed. Columbia: Columbia University Press.

Chibber, Vivek (2003) Locked in place: state-building and late industrialization in India. Princeton: Princeton UP.

Das, Samarendra and Felix Padel (2010) Out of this earth. Delhi: Orient Blackswan.

Davy, Ulrike (2013) Social citizenship going international: changes in the reading of UN-sponsored economic and social rights. International Journal of Social Welfare 22, S15-S31.

Davy, Benjamin, Ulrike Davy, and Lutz Leisering (2013) The global, the social and rights: new perspectives on social citizenship. International Journal of Social Welfare 22: S1-S14.

Davy, Benjamin and Sony Pellissery (2013) The citizenship promise (un) fulfilled: the right to housing in informal settings. International Journal of Social Welfare 22,1: S68-S84.

Down to Earth (2005) Rise of third sector. https://www.downtoearth.org.in/coverage/rise-of-third-sector-33712 (accessed on 20/04/2020). 
Dumont, Louis (1966) Homo hierarchicus: the caste system and its implications. Chicago: University of Chicago Press.

Fanon, Frantz (1967) Black skin, white masks. New York: Grove Press.

Fraser, Nancy and Axel Honneth (2003) Redistribution or recognition? London: Verso.

Gadamer, Hans (1976) Hegel's dialectic of self-consciousness. In: Hegel's dialectic: Five hermeneutical studies, P. Christopher Smith (trans.), New Haven: Yale University Press, 54-74.

Galanter, Marc (1984) Competing equalities: law and the backward classes in India. New Delhi: Oxford University Press.

Haragopal, Gudavarthy and Sukumar (2007) Cultural roots of undemocratic order. In Ambedkar in retrospect, eds. Sukhadeo Thorat and Aryama, Rawat Publications, Jaipur, 292-300.

Heclo, Hugh (1995) Social Question In) Poverty, inequality and the future of social policy, eds. Katherine McFate, Roger Lawson, and William Julius Wilson, London: Russel Sage Publications, 665-691.

Hegel, Georg Wilhelm Friedrich (1807/1966) The phenomenology of mind. London: Allen and Unwin.

Honneth, Axel (2014) The I in we: studies in the theory of recognition. Cambridge: Polity.

Iliah, Kancha. (2007) Indian counter culture. In Ambedkar in retrospect, eds. Sukhadeo Thorat and Aryama, Jaipur: Rawat Publications, 301-314.

Jalal, Ayesha (1995) Democracy and authoritarianism in South Asia. Cambridge: Cambridge University Press.

Jayal, Niraja Gopal (2011) A false dichotomy? The unresolved tension between universal and differentiated citizenship in India. Oxford Development Studies, 39,2:185-204.

Jeyaranjan, J., John Harriss, and K Nagaraj (2010) Land, labour and caste politics in rural Tamil Nadu in the 20th century: Iruvelpattu (1916-2008). Economic and Political Weekly 45,31: 47-61.

Johari, J. C. (1973) Young Turks and the radicalisation of the Congress leadership. The Indian Journal of Political Science 34,2:173-198.

Kane, Pandurang Vaman (1941) History of Dharmasastras: part I. Poona: Bhandarkar Oriental Research Institute

Kaufmann, Franz-Xaver (2012) European foundations of the welfare state. New York: Berghahn Books.

Kaufmann, Franz-Xaver (2013) Thinking about social policy. The German Tradition. German Social Policy 1, ed. Lutz Leisering. Berlin et al.: Springer. 
Kaur, Balbir, Atri Mukherjee, Neeraj Kumar and Anand Prakash Ekka (2014) Debt sustainability at state level in India, RBI Working Paper Series WPS (DEPR): 07/2014.

Keefer, Philip and Stuti Khemani, (2005) Democracy, public expenditure and the poor. The World Bank Research Observer 20,1: 1-27.

Kojève, Alexandre (1969) Introduction to the reading of Hegel. New York: Basic Books.

Kosambi, Damodar Dharmananda (1954) Stages of Indian history. Journal of the Indo-Soviet Cultural Society 1,1:11-19.

Kosambi, Damodar Dharmananda (1955) The basis of ancient Indian history. Journal of the American Oriental Society 75:35-45.

Marx, Karl (1853) Marx to Engels, 14 June 1853. https://marxists.architexturez. net/archive/marx/works/1853/letters/53_06_14.htm (accessed on 30/09/2019).

Marx, Karl (1858) Grundrisse. marxists.org/archive/marx/works/1857/grundrisse/ch09.htm\#p471 (accessed on 30.09/2019).

Mannoni, Octave. (1962) Prospero and Caliban: The psychology of colonization. New York: Praeger.

Mathew, Babu, Sony, Pellissery, and Arvind, Narrain (2020) Why is law central to policy process in Global South? In Transformative law and public policy, eds. Sony, Pellissery, Babu Mathew, Avinash Govindjee, and Arvind Narrain,, New Delhi: Routledge, 1-25.

Metcalfe, Charles (1833) Appendix to the Report from the Select Committee of the House of Commons on the Affairs of the East-India Company, III-Revenue (London House of Parliament Archives).

Mkandawire, Thandika (2001) Social policy in a development context. UNRISD Working Papers PP-SPD-7.

Midgley, James. and Kwong-leung Tang (2001) Social policy, economic growth and developmental welfare. International Journal of Social Welfare 10:244-252.

Nussbaum, Martha (2003) Capabilities as fundamental entitlements: Sen and social justice. Feminist Economics 9 (2-3): 33-59.

Omvedt, Gail (2007) Towards a theory of caste and class. in Ambedkar in retrospect, eds. Sukhadeo Thorat and Aryama, Rawat Publications, Jaipur, 246-260. Pellissery, Sony (2006) The politics of social protection in rural India. Doctoral Dissertation Submitted to University of Oxford.

Pellissery, Sony and Sattwick Dey Biswas (2012) Emerging property regimes in India: what it holds for the future of socio-economic rights? IRMA Working Paper. 
Pellissery, Sony, Amrutha Jose Pampackal, and, Partha Bopaiah (2015) Caste and distributive justice: can social policy address durable inequalities?. Social Policy \& Administration 49, 6: 785-800.

Pellissery, Sony (2016) Land alienation infused poverty in India. In Poverty and inequality in middle-income countries, eds. Einaar Braathen, Julian May, and Gemma Wright, London: Zed: 130-56.

Pellissery, Sony (2017) Social investments and poor families in India. In Social investment and social welfare, eds. James Midgley, Espen Dahl, and Amy Conley Wright, Cheltenham: Edward and Elgar, 70-86.

Pellissery, Sony, Ben Davy and Harvey Jacobs (2017) Land Policies in India, Singapore: Springer.

Pellissery, Sony and Vivek Anand (2017) Social investment regimes in India. Conference paper presented at Sciences Po, Paris during 9-12 March 2017.

Pellissery, Sony, Sharada Srinivasan, and Anusha Chaitanya (2020) Politics of making and unmaking of the Indian Planning Commission. In Transformative law and public policy, eds. Sony Pellissery, Babu Mathew, Avinash Govindjee, and Arvind Narrain, New Delhi: Routledge, 111-127.

Pellissery, Sony and Partha Bopaiah (2020) Corruption and social policy. In Oxford Handbook of Public Administration for Social Policy, Oxford: Oxford University Press: (forthcoming).

Platteau, Jean-Philippe (1990) Traditional systems of social security and hunger insurance. In Social security in developing countries, eds. Ehtisham Ahmad, Jean Dreze, John Hills, and Amartya Sen, Oxford: Clarendon Press, 112-170.

Rajan, Nalini (2003) Left liberalism and caste politics. Economic and Political Weekly 38,24:2346-49.

Ramavat, Pradeep (2018) From millions to fractions: re-examining pragmatism in the context of internal reservation. Occasional paper series $04 / 2018$ of the Institute of Public Policy, Bangalore.

Reddy, G. Ram and Gudavarthy Haragopal (1985) The Pyraveekar: "the fixer" in rural India. Asian Survey 25,11: 1148-1162.

Rothstein, Bo (2005) Social traps and the problem of trust. Cambridge: Cambridge University Press.

Sharma, R. S. (1984) How feudal was Indian feudalism?. The Journal of Peasant Studies 12,2: 19-43.

Sanyal, Kalyan (2007) Rethinking capitalist development. Routledge, London. Sen, Pronab (2017) Plan, but do not over-plan: Lessons for NITI Aayog. Economic and Political Weekly 52,18: 41-48. 
Siegel, Benjamin Robert (2018) Hungry nation. Cambridge: Cambridge University Press.

Singh, Hira (2014) Recasting caste-from the sacred to the profane. Sage Publications, New Delhi.

Srinivas, Mysore Narasimhachar and Arvind M. Shah (1960) The myth of selfsufficiency of Indian village. The Economic Weekly (Sept 10).

Suryanarayana, M. (1995) PDS: Beyond implicit subsidy and urban bias- the Indian experience. Food Policy 20,4: 259-278.

Taylor, Charles (1992) Multiculturalism and the politics of recognition. In Multiculturalism, ed. Amy Gutmann, Princeton: Princeton University Press: 25-73.

Thapar, Romila (1966) History of India. Penguin Books, New Delhi.

Tönnies, Ferdinand (1887/2001) Community and civil society. Cambridge: Cambridge University Press.

Young, Iris Marion (2000) Inclusion and democracy. Oxford: Oxford University Press.

Wade, Robert (1985) The market for public office: why the Indian state is not better at development. World Development 13,4: 467-497.

World Bank (2004) Making the services work for the poor people. Washington: World Bank.

World Bank (2011) Poverty and social exclusion. World Bank, New Delhi.

Open Access This chapter is licensed under the terms of the Creative Commons Attribution 4.0 International License (http://creativecommons.org/ licenses/by/4.0/), which permits use, sharing, adaptation, distribution and reproduction in any medium or format, as long as you give appropriate credit to the original author(s) and the source, provide a link to the Creative Commons licence and indicate if changes were made.

The images or other third party material in this chapter are included in the chapter's Creative Commons licence, unless indicated otherwise in a credit line to the material. If material is not included in the chapter's Creative Commons licence and your intended use is not permitted by statutory regulation or exceeds the permitted use, you will need to obtain permission directly from the copyright holder.

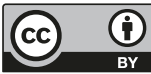

